International Journal of Instruction e-ISSN: 1308-1470 • www.e-iji.net

Article submission code: 20201019124949

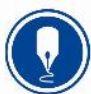

October $2021 \bullet$ Vol.14, No.4

p-ISSN: 1694-609X

pp. 1-20

Received: 19/10/2020

Revision: 15/02/202
Accepted: 10/03/2021

OnlineFirst: 05/07/2021

\title{
Academic Achievement and Delay: A Study with Italian Post-Graduate Students in Psychology
}

\section{Massimiliano Barattucci}

Asst. Prof., Faculty of Psychology, eCampus University, Novedrate (CO), Italy, massimiliano.barattucci@uniecampus.it

\section{Yusuf F. Zakariya}

Department of Mathematical Sciences, Faculty of Engineering and Science, The University of Agder, Kristiansand, Norway, yusuf.zakariya@uia.no

\section{Tiziana Ramaci}

Prof., Faculty of Human and Social Sciences, Kore University of Enna, (EN), Italy, tiziana.ramaci@unikore.it

Using the Biggs' 3P learning model and correlational design, this study explores the relationship between students' individual characteristics and course perceptions, approach to study, and academic outcomes, which account for the differences in academic achievement and student delay. 612 Italian students of a master's degree in psychology participated by completing a questionnaire with measures of Presage (prior school background, motivation, self-efficacy, course perceptions), Process (approach to study, class attendance and autonomy in learning) and Product of learning (achievement, delay, satisfaction). Regression analysis and Structural Equation Modelling showed that prior school background directly predicts achievement and delay, while motivation, self-efficacy, teaching and workload perceptions, jointly predict achievement through approach to study. The results underlined differences between on time and delayer students that should be given due consideration by academic institutions in order to develop correct processes and practices that support students on their academic path.

Keywords: achievement, delay, approach to study, prior school background, motivation, self-efficacy, course perceptions

\section{INTRODUCTION}

Universities operate in a global market and have worked hard to improve learning standards, teaching quality monitoring, student services and course organisation, striving to offer a training product able to satisfy both student expectations and the demand for specific skills from a rapidly changing labour market that only accepts a high level of preparation (Wright \& Osman, 2018). As a result of these scenario changes, academic institutions have structured and reworked their policies based on the perceptions, needs

Citation: Barattucci, M., Zakariya, Y. F., \& Ramaci, T. (2021). Academic achievement and delay: A study with Italian post-graduate students in psychology. International Journal of Instruction, 14(4), 1 20. https://doi.org/10.29333/iji.2021.1441a 
and characteristics of their students, paying close attention to their course experience to intervene on teaching and tutoring practices, and to provide a continuously improving academic service (Entwistle \& McCune, 2004; Santisi et al., 2018). Understanding students' perceptions of the learning settings and their personal background allows for the analysis of the variations in study results and make it possible to take action on the learning environment, study programmes and paths, and on specific problem situations such as disengagement and progression (Hattie, 2009; Lo, 2012). Relying on Biggs' 3P learning process model (2003), which allows the contribution of different variables to be taken into account in predicting learning outcomes, the research was aimed at understanding which factors have the most impact in accounting for the differences in achievement and delay for students (Braxton et al., 2000; Neuville et al., 2007; Schneider \& Preckel, 2017). More specifically, the paper focused on testing if student's perceptions and characteristics influence academic delay through the adoption of specific approaches to study.

\section{Approach to Study and Learning Outcomes}

Research which addresses the impact of student characteristics and perceptions of the learning environment on study outcomes, has often been framed within the Biggs' 3P model (2003), which conceptualises the learning process as an interactive system of three sets of variables: students' personal characteristics and course perceptions (as Presage variables), approach to study (as a learning Process) and learning outcomes (as learning Product). As indicated by this model, personal and environmental factors predict the adoption of specific approaches to study, which have effect on learning outcomes (Figure 1). The model is employed with two main theoretical approaches: a systemic one (Biggs \& Tang, 2007), and a phenomenographic approach, the Student Learning Perspective (Lo \& Marton, 2012; Prosser et al., 2005; Tight, 2016). Although there is interest in the different theoretical approaches in exploring the variation in study performance, much of the literature is mainly focused on the environmental and learning process variables that positively influence study outcomes and much less on those related to learning difficulties (Malau-Aduli et al., 2020). Moreover, despite the importance of understanding the factors behind academic problematic paths, several studies have focused much more on implied psychological variables in academic procrastination or bad habits (waste of time, addictions, use of mobile phone, etc.) rather than on difficulties in university studies related to the learning process, academic life or student's background (Lowinger et al., 2016).

\section{Course Experience, Study Process and Academic Achievement}

Many studies have investigated the role of perceptions of the learning environment, course experience and approach to study on academic achievement and other learning outcomes (Richardson et al., 2012; Schneider \& Preckel, 2017). In general, course experience factors (especially teaching evaluation and workload perception) positively predict a deep and strategic approach to study and negatively predict a surface approach to learning (Diseth \& Kobbeltvedt, 2010; Fryer \& Ginns, 2017; Martin, 2019; Trigwell et al., 2013); even though some studies found that perceptions of the academic context affect academic performance (Baeten et al., 2013; Diseth, 2007; Karagiannopoulou \& 
Milienos, 2015), the relationship between student perceptions and study outcomes, has not been fully clarified (Howie \& Bagnall, 2013; Steinmayr et al., 2014).

According to much of the research, the adoption of a surface approach to study is associated with worse workload perceptions, while a deep approach to study is related to better teaching quality (Diseth, 2013; Lizzio et al., 2002; Trigwell et al., 2013). However, conflicting results seems to show a more evident connection between approach to study and specific learning outcomes (satisfaction, key skills, understanding of educational goals, etc.), rather than achievement (grades) (Byrne et al., 2002; Karagiannopoulou \& Milienos, 2015; Trigwell et al., 2013; Ward, 2011; Yonker, 2011).

In addition to environmental perception and approach to study, motivation and prior school and academic performance have been shown to have a direct influence on learning outcomes (Pintrich \& Schunk, 2002; Steinmayr et al., 2015; Zeegers, 2004;); achievement, furthermore, is affected by other personal factors such as gender (Spinath et al., 2014; Van Bragt, 2011;), age (Navarro, García-Rubio et al., 2015) and social interaction (Cornelius-White et al., 2010).

\section{Academic Delay and Difficulties}

The Italian academic system allows students to delay their graduation beyond the standard period and without any limitation on how long this delay can be. Although this is a positive in terms of the right to education, it can result in situations where studies are delayed for long periods with students lacking a sense of responsibility, often resulting in dropout (Magnano et al., 2020; Perchinunno et al., 2019).

Despite the practical importance of this issue, almost no research has looked at this delay in studies in similar academic contexts. If we look at research on academic procrastination, in spite of the many studies on this issue, it is not clear what the main causes and effects are (Hen \& Goroshit, 2020), although some scientific evidence has been collected on the negative relationship between self-efficacy, motivation, selfregulation and students' academic problems (Tinto, 2007; Zacks \& Hen, 2018).

Research investigating the relationship between academic difficulties and environmental factors or learning processes, on the contrary, is practically absent (Bembenutty \& Karabenick, 2004). A few studies have shown that withdrawal from academic studies is related to dissatisfaction with the quality of teachers and other academic perceptions, as well as to the lack of interaction in the academic environment (Geisinger \& Raman, 2013). Furthermore, some indications underline that academic failure is related to schooling background, GPA and both social and academic integration with the study environment (Mannan, 2007; Paul et al., 2009).

A study of Italian undergraduate students (Barattucci et al., 2017) revealed that course perceptions are weak predictors of achievement, while study approach seems not to mediate the relationship between presage factors and products. However, the research did not consider differences between normal students and delayers.

In order to address this knowledge gap, a correlational study with Italian Post-graduate students was designed using the Biggs's 3P model of learning (2003), to explore the 
factors with most influence on achievement and delay and to test the mediation role of approach to study on antecedents and outcomes. The information provided by the research may support the understanding of the specific modifiable environmental and study process variables related to academic delay.

\section{Objectives and Hypotheses}

Utilising an adapted 3P learning model (Biggs, 2003), the present paper suggests that the effects of Presage variables on student academic outcome (Products) are driven by study process factors (approach to study and study factors) (Figure 1).

PRESAGE

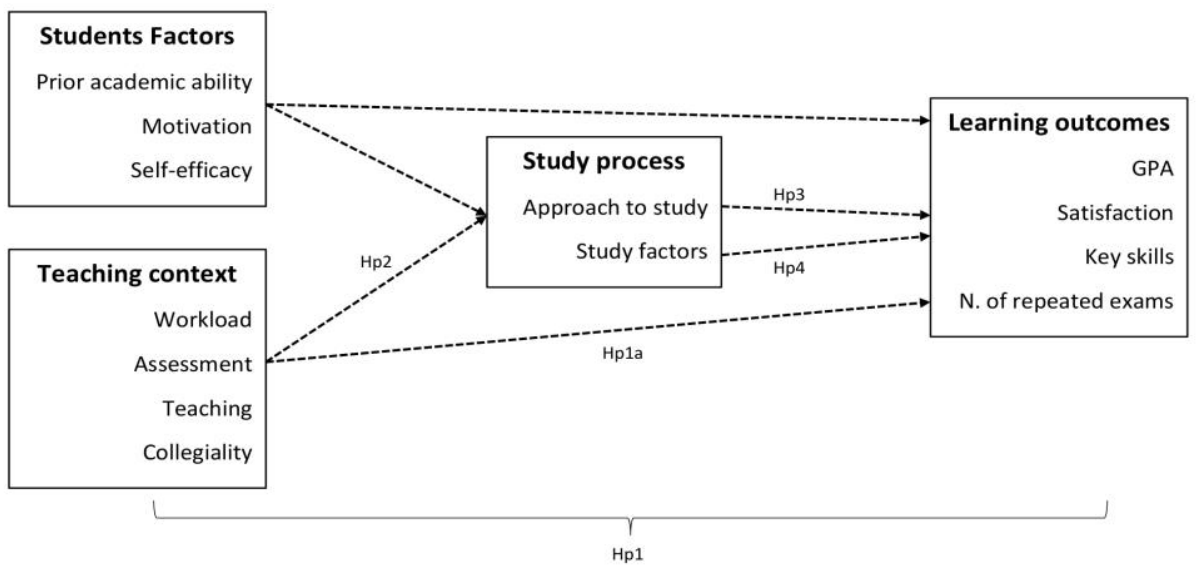

Figure 1

Adapted 3P Learning Process Model (Biggs, 1989)

The study aims to explore which factors and perceptions can predict differential approaches to study, which impact on student achievement and delay. The study selected variables from an adapted version of the 3P learning process model (Barattucci et al., 2017) and from a review of the literature relating to academic difficulties (schooling background; autonomy in learning and class attendance as study factors linked to social and academic integration) (Geisinger \& Raman, 2013; Mannan, 2007; Paul et al., 2009; Zacks \& Hen, 2018)

Using this model, student's background, personal variables (motivation, and selfefficacy), learning environment perceptions (appropriate workload, appropriate assessment, collegiality, and teaching quality) and approaches to study (deep and surface), together with study process variables (class attendance and autonomy), were selected to be analysed together with students' academic achievement (GPA) and delay (number of repeated exams).

It was predicted that prior academic ability of students, personal factors and perceptions of the learning environment, through the adoption of specific study process factors, 
would jointly influence achievement and delay (Hp1). In particular, it was hypothesised that perceptions of the learning environment would influence achievement and delay through the adoption of specific study process factors (Hpla). A series of lower-order hypothesis were taken into consideration and tested. We expected that qualitatively different perceptions of the learning environment would be related to different approaches to study ( $\mathrm{Hp} 2)$. It was predicted that students' positive perceptions of the learning environment would be associated with a deep approach to study (Hp2a) and that less favourable perceptions of the learning environment would be associated with a superficial approach to study (Hp2b). Moreover, it was predicted that course perceptions would affect study process factors (class attendance and autonomy in learning) (Hp2c) and learning outcomes $(\mathrm{Hp} 2 \mathrm{~d})$. It was also predicted that approach to study would have a direct effect on academic achievement and delay (Hp3), with a deep approach associated with better academic outcomes than a surface approach. Study process factors (class attendance and autonomy in learning) were expected to influence academic outcomes and delay ( $\mathrm{Hp} \mathrm{4).} \mathrm{It} \mathrm{was} \mathrm{thereby} \mathrm{hypothesised} \mathrm{that} \mathrm{there} \mathrm{would} \mathrm{be}$ significant differences in schooling background, personal factors, course experience, approach to study, study factors and achievement between "on time" and "not on time" students (Hp5). Knowing which of these factors most foster a positive approach to study and participation in academic life, which can ultimately impact on delay, would be helpful to enable universities and faculties to tailor organisational activities and improvements, targeting specific dimensions of the perceived supportive environment, as well fostering individual support activities to prevent study delay or dropout (Lo \& Marton, 2012).

\section{METHOD}

\section{Participants and Procedure}

The final sample consisted of 612 students, 490 (80.1\%) women and 122 (19.9\%) men (Table 1). $94 \%$ of students were aged between 21 and 26 years, the mean age was 23.68 years $(\mathrm{SD}=4.01)$, with a slight difference between men (mean age $=24.52, \mathrm{SD}=4.31)$ and women (mean age $=23.27$, SD 3.9). Students were all enrolled on a postgraduate Psychology course, predominantly in the first year $(\mathrm{N}=240 ; 39.2 \%)$ and second year $(\mathrm{N}$ $=249 ; 40.7 \%)$ of studies. About a fifth of the sample were students who had not completed their course exams, in Italy aptly named "out of course students", who are extended term students $(\mathrm{N}=123 ; 20.1 \%)$.

Table 1

Sample description [average age: mean value (SD)]

\begin{tabular}{lllll}
\hline & Total & $1^{\circ}$ year & $2^{\circ}$ year & Extend. time \\
\hline $\mathrm{N}^{\circ}$ & 612 & 240 & 249 & 123 \\
\hline Females & 487 & 195 & 203 & 89 \\
\hline Males & 125 & 45 & 46 & 34 \\
\hline Average age & $23.68(4.01)$ & $22.54(3.89)$ & $23.47(4.02)$ & $24.18(3.95)$ \\
\hline
\end{tabular}


Students from the psychology faculty of an Italian university voluntarily participated in the study by individually and anonymously completing a questionnaire. The subjects were students of the two-year master's degree in Psychology, enrolled in the 2014-2015 and 2015-2016 academic year. Students were recruited on campus, after the mandatory first year exam, and invited to subsequently complete a questionnaire about their university experience. Before submission of the questionnaire, students were given general completion instructions. Overall, 631 students completed the questionnaire, 19 of them did not fully complete the test (missing $>5 \%$ ) and the related data was excluded from the subsequent analyses. The collected sample covered $79 \%$ of the total population of students enrolled in a master's degree in psychology at the University. Respondents received a copy of the questionnaire, along with a letter outlining the research and a sealable envelope to protect their privacy (Italian Law No. 196/2003). Questionnaires were distributed by trained researchers and participation was voluntary. Completed questionnaires were collected after 1 day. Students were informed that they could end their participation at any time. The study complied with ethical standards and was approved by the Ethical Committee of the author's institution.

\section{Instruments}

Data was collected for the following variables of interest: prior academic ability (school grades: range 60 - 100, supplied by students); final undergraduate degree grades: range $66-110$, supplied by students; personal factors (motivation and self-efficacy); perceptions of the learning environment (appropriate assessment, appropriate workload, good teaching, collegiality); approaches to study (deep approach, surface approach); study factors (class attendance, autonomy, work status); learning outcomes (satisfaction, key skills, average test score: average user rating for declared exams, a variable similar to grade point average - GPA, measured on a scale from 18.00 (lowest average rating) to 30.00 (highest average rating), supplied by students; number of repeated exams: total number of repeated examinations declared per curriculum, supplied by students.

Motivation was assessed through eight items (e.g. "I like the subject matter of my degree") adapted from the Motivated Strategies for Learning Questionnaire (Pintrich et al., 1989). Responses were given through a 5-point scale (from $1=$ "completely disagree" to 5 = "completely agree").

Self-efficacy was assessed through four items (e.g. "I'm certain I can understand the most difficult material on my reading lists") adapted from the Motivated Strategies for Learning Questionnaire (Pintrich et al., 1989). Responses were given through a 5-point scale (from $1=$ "completely disagree" to 5 = "completely agree).

Perceptions of the learning environment were measured through the Student Course Experience Questionnaire (SCEQ), in the Italian form of 23 items (Barattucci \& Zuffo, 2012), including appropriate workload, good teaching, collegiality and appropriate assessment scales. Responses were given through a 5-point scale (from $1=$ "completely disagree" to $5=$ "completely agree"). 
Approaches to study were measured through the Approach to Study Inventory, in the Italian form of 12 items (Barattucci \& Zuffo, 2012), including deep approach and surface approach scales. Responses were given through a 5-point scale (from $1=$ "completely disagree" to $5=$ "completely agree").

Class attendance was measured by students' responses to the item "I attended lessons", rated on 4-point Likert scale from ("for less than $25 \%$ of the classes") to 4 ("for more than $75 \%$ of the classes").

Autonomy in learning was measured by students' responses to the item "Without receiving helpful information from colleagues and professors, I manage", rated on 4point Likert scale from 1 ("less than $25 \%$ of exams) to 4 (more than $75 \%$ of exams).

Key skills were assessed through seven items (e.g., "My degree course has developed my problem-solving skills"), part of the Italian Student Course Experience Questionnaire (SCEQ) (Barattucci \& Zuffo, 2012) and responses were given through a 5-point scale (from 1 = "completely false" to 5 = "completely true").

Satisfaction for the course was evaluated with a single item ("Overall, I am satisfied with the quality of this course"), rated on a 5-point Likert scale from 1 (disagree) to 5 (agree).

\section{FINDINGS}

\section{Data Analysis}

The design of the research was correlational. To verify the specific hypotheses, correlation, t-test and regression analyses with SPSS 21.0 were conducted. To verify the goodness-of-fit of the measurement and proposed models, structural equation modelling with LISREL 8.7 was performed (Jöreskog \& Sorbom, 2001).

\section{Measurement Model}

Following the indications of Anderson \& Gerbing (1988), CFA through LISREL 8.7 was conducted to analyse the construct validity and reliability of the measurement model made up of the used scales (SCEQ+ASI+Motivation and Self-Efficacy, 9 scales in total). We compared four different nested models based on goodness of fit indices, from a single factor model to a model (to be confirmed) with nine factors. Passing from model A to model D, results showed a general increase of all indices (Table 2).

Table 2

Goodness of fit indices of the different tested measurement models

\begin{tabular}{lllll}
\hline & $\mathrm{Chi}^{2} / \mathrm{df}$ & RMSEA & CFI & SRMR \\
\hline Model A - One factor & 14.81 & .196 & .379 & .285 \\
\hline Model B - 3 factors & 7.84 & .124 & .628 & .190 \\
\hline Model C - 6 factors & 4.76 & .109 & .835 & .018 \\
\hline Model D - 9 factors & 2.89 & .092 & .910 & .087 \\
\hline
\end{tabular}

If, on one hand, the final 9-factor model showed only acceptable values, results concerning Average variance extracted (AVE), Composite Reliability (CR), internal 
consistencies and factor loadings (all higher than .60), showed decent scores (Table 3), overall corroborating a reliable measurement model with items referring to their proper factor. Table 4 shows correlations among the variables measured by the study.

Table 3

Validation of the final measurement model: reliability and convergent validity

\begin{tabular}{llllll}
\hline Scale & Items & $\alpha$ & AVE & Mean & Std. Dev. \\
\hline Appropriate Workload & 4 & .742 & .71 & 2.91 & .88 \\
\hline Good Teaching & 6 & .754 & .74 & 2.75 & .67 \\
\hline Collegiality & 3 & .708 & .62 & 3.1 & .82 \\
\hline Appropriate Assessment & 3 & .682 & .58 & 3.1 & .82 \\
\hline Key Skills & 7 & .720 & .59 & 3.47 & .66 \\
\hline Motivation & 8 & .807 & .78 & 4.11 & .55 \\
\hline Self-efficacy & 4 & .695 & .70 & 3.72 & .66 \\
\hline Deep Approach & 6 & .725 & .66 & 3.95 & .57 \\
\hline Surface Approach & 6 & .693 & .68 & 3.95 & .69 \\
\hline
\end{tabular}

Table 4

Correlations of all the scales used in the study

\begin{tabular}{|c|c|c|c|c|c|c|c|c|c|}
\hline & 1 & 2 & 3 & 4 & 5 & 6 & 7 & 8 & 9 \\
\hline 1. Motivation & 1 & & & & & & & & \\
\hline 2. Self-efficacy & $.466 * * *$ & 1 & & & & & & & \\
\hline 3. Appr. Assessment & $.111 * *$ & n.s. & 1 & & & & & & \\
\hline 4. Appr. Workload & $.109 * *$ & $.208 * *$ & $.146 * *$ & 1 & & & & & \\
\hline 5. Good Teaching & $.415 * * *$ & $.221 * *$ & $.128 * *$ & $.163 * *$ & 1 & & & & \\
\hline 6. Collegiality & $.258 * *$ & $.218 * *$ & n.s. & n.s. & $.334 * *$ & 1 & & & \\
\hline 7. Deep Approach & $.479 * *$ & $.413 * *$ & $.115^{*}$ & $.091 * *$ & $.176^{* *}$ & $.297 * *$ & 1 & & \\
\hline 8. Surface Approach & $-.320 * *$ & $-.374 * *$ & $-.194 * *$ & $-.358 * *$ & $-.216^{* *}$ & $-.133 * *$ & $-.245^{* *}$ & 1 & \\
\hline 9. Key Skills & $.492 * *$ & $.382 * *$ & $.086^{*}$ & n.s. & $.412 * *$ & $.355 * *$ & $.340 * *$ & $.382 * *$ & 1 \\
\hline
\end{tabular}

Effect of gender and age on study process and outcomes. In order to check for gender differences, a series of independent sample t-tests were performed. Gender differences only emerged for the number of repeated exams: women have fewer repeated examinations $\left(\mathrm{t}_{612}=3.7 ; \mathrm{p}<.001\right)$ than men. A series of multiple regression analyses to explore the effect of age were carried out. Age significantly predicted collegiality (F ( 1 , $611)=5.64 ; \beta=-.10, p<.01)$, deep approach $(\mathrm{F}(1,611)=7.08 ; \beta=.11, \mathrm{p}<.01)$, 
surface approach $(\mathrm{F}(1,611)=13.49 ; \beta=-.15, \mathrm{p}<.001)$, and class attendance (F (1, $611)=5.09 ; \beta=-.092, p<.05)$. As the student gets older, they use more deep approach and less surface approach strategies (Asikainen \& Gijbels, 2017), while they begin to attend less class lessons and engage less in campus life.

\section{Presage on Process}

Prior academic ability on study process. Multiple regression analyses showed an effect of school grades on the deep approach scale $(\mathrm{F}(1,611)=5.33 ; \beta=.095, \mathrm{p}<.05)$, and autonomy in learning $(\mathrm{F}(1,611)=10.86 ; \beta=-.136, \mathrm{p}<.001)$. Students with higher school grades have deeper study strategies and tend to study more in peer groups than students with lower school grades. Final undergraduate degree grades predict deep approach $(\mathrm{F}(1,611)=9.82 ; \beta=.362 ; \mathrm{t}=3.133 ; \mathrm{p}<.001)$ and class attendance $(\mathrm{F}(1$, $611)=7.5 ; \beta=.322 ; \mathrm{t}=2.74 ; \mathrm{p}<.01)$.

Personal factors on study process. Motivation predicts deep approach $(\mathrm{F}(1,611)=$ $213.7 ; \beta=.514 ; \mathrm{t}=14.619, \mathrm{p}<.001)$, surface approach $(\mathrm{F}(1,611)=81.7, \beta=-.047 ; \mathrm{t}$ $=-9.04, \mathrm{p}<.001)$ and class attendance $(\mathrm{F}(1,611)=5.44, \beta=.095 ; \mathrm{t}=2.333, \mathrm{p}<.05)$. Self-efficacy does not predict any study process factor.

Course perceptions on study process factors. Globally, perceptions of the academic environment are valid predictors both of deep approach to study $\left(\mathrm{F}_{4,611}=10.75 ; \mathrm{R}^{2}=\right.$ $.08(.55) ; \mathrm{p}<.001)$ and of the surface approach $\left(\mathrm{F}_{4,611}=50.2 ; \mathrm{R}^{2}=.253(.62) ; \mathrm{p}<\right.$ $.001)$. More specifically, collegiality and appropriateness workload scales significantly predicted deeper study strategies, while all scales, except appropriate assessment, emerged as significant predictors of surface approach to study (Table 5).

Table 5

Multiple regression of SCEQ as predictors of approaches to study and study process factors

\begin{tabular}{|c|c|c|c|c|c|c|c|c|c|c|c|c|}
\hline \multirow{2}{*}{$\begin{array}{l}\text { SCEQ } \\
\text { SCALES }\end{array}$} & \multicolumn{3}{|c|}{ Deep Approach } & \multicolumn{3}{|c|}{ Surface Approach } & \multicolumn{3}{|c|}{ Class attendance } & \multicolumn{3}{|c|}{$\begin{array}{l}\text { Autonomy in } \\
\text { learning }\end{array}$} \\
\hline & B & Beta & $\mathrm{t}$ & B & Beta & $\mathrm{t}$ & B & Beta & $\mathrm{t}$ & B & Beta & $\mathrm{t}$ \\
\hline $\begin{array}{l}\text { Appr. } \\
\text { Workload }\end{array}$ & .051 & .081 & $2.11^{*}$ & $\begin{array}{l}- \\
.372\end{array}$ & $\begin{array}{l}- \\
.453\end{array}$ & $-12.48 * * *$ & .125 & .099 & $2.77 *$ & .008 & .006 & .144 \\
\hline $\begin{array}{l}\text { Appr. } \\
\text { Assessment }\end{array}$ & .016 & .027 & .720 & $\begin{array}{l}- \\
.017\end{array}$ & $\begin{array}{l}- \\
.022\end{array}$ & -.626 & .122 & .095 & $2.91 *$ & .038 & .032 & .765 \\
\hline Good Teaching & .057 & .070 & 1.58 & $\begin{array}{l}- \\
.088\end{array}$ & $\begin{array}{l}- \\
.085\end{array}$ & $-2.157^{*}$ & .024 & .014 & .32 & .023 & .014 & .31 \\
\hline Collegiality & .120 & .200 & $4.63 * * *$ & $\begin{array}{l}- \\
.076 \\
\end{array}$ & $\begin{array}{l}- \\
.104 \\
\end{array}$ & $-2.931 * *$ & .384 & .302 & $7.11 * * *$ & .044 & .036 & .81 \\
\hline $\mathrm{R}^{2}$ & $.08^{* *}$ & & & $.253^{*}$ & & & $.12 * *$ & & & .003 & & \\
\hline
\end{tabular}

Overall, results seem to confirm hypothesis $\mathrm{Hp} 2$ and to show that perceptions of the learning environment are more related with surface $(\mathrm{Hp} 2 \mathrm{~b})$ than a deep approach to 
study (Hp2a). Altogether, perceptions of the academic environment are valid predictors of class attendance $\left(\mathrm{F}_{4,610}=19.38 ; \mathrm{R}^{2}=.12(1.14) ; \mathrm{p}<.001\right)$ but not of autonomy in learning $\left(\mathrm{F}_{4,610}=.468 ; \mathrm{R}^{2}=.003(1.1)\right.$; n.s. $)$. The more a student has the perception of appropriate workload, assessment and collegiality, the more they attend class lessons. Overall, the hypothesis $\mathrm{Hp} 2 \mathrm{c}$ was only confirmed for class attendance.

\section{Presage on Outcomes}

Prior academic ability on outcomes. The results of the one-way ANOVA indicated that a high school diploma (professional, technical, lyceum) is a predictor of average test scores $\left(\mathrm{F}_{2,609}=5,017 ; \mathrm{p}<.01\right)$ : students with lyceum school diplomas achieve higher average test scores $(\mathrm{M}=26.09 ; S D=1.13$ ), than other schools (professional schools, $\mathrm{M}$ $=24.85 ; S D=1.57$; technical schools, $\mathrm{M}=25.27 ; S D=1.30$ ). In addition, high school grades emerged as a strong predictor of average test scores $(\mathrm{F}(1,611)=100.647 ; \beta=$ $\left..398 ; \mathrm{t}_{612}=10.032 ; \mathrm{p}<.001\right)$, and of the number of repeated examinations $(\mathrm{F}(1,611)=$ $\left.57.477 ; \beta=-.304 ; \mathrm{t}_{612}=-7.581 ; \mathrm{p}<.001\right)$. The final undergraduate degree grade predicts average test scores $\left(\mathrm{F}(1,611)=33.73 ; \beta=.603 ; \mathrm{t}_{612}=5.81 ; \mathrm{p}<.001\right)$, number of repeated exams $\left(\mathrm{F}(1,611)=15.542 ; \beta=-.448 ; \mathrm{t}_{612}=-3.942 ; \mathrm{p}<.001\right)$ and course satisfaction $\left(\mathrm{F}(1,611)=7.34 ; \beta=.319 ; \mathrm{t}_{612}=2.709 ; \mathrm{p}<.01\right)$.

Personal factors on outcomes. Only motivation is a predictor of the number of repeated exams $\left.\left(\mathrm{F}(1,611)=12.036, \mathrm{p}<.001 ; \mathrm{R}^{2}=.040\right) ; \beta=-.171, \mathrm{t}_{612}=-.4 .81, \mathrm{p}<.001\right)$. Both motivation $\left(\beta=.080 ; \mathrm{t}_{612}=1.981 ; \mathrm{p}<.05\right)$ and self-efficacy $\left(\beta=.110 ; \mathrm{t}_{612}=\right.$ $2.393 ; \mathrm{p}<.05)$ are predictors of average test scores $\left(\mathrm{F}(1,611)=6.8, \mathrm{p}<.001 ; \mathrm{R}^{2}=\right.$ $.026)$. Both motivation $\left(\beta=.520, \mathrm{t}_{612}=14.02, \mathrm{p}<.001\right)$ and self-efficacy $\left(\beta=.11, \mathrm{t}_{612}=\right.$ $2.993, \mathrm{p}<.001)$ are predictors of satisfaction $\left(\mathrm{F}(1,611)=146.7 ; \mathrm{p}<.001 ; \mathrm{R}^{2}=.331\right)$ and key skills $\left(\mathrm{F}(1,611)=97.52, \mathrm{p}<.001, \mathrm{R}^{2}=.247\right.$. Motivation: $\beta=.444, \mathrm{t}_{612}=$ $11.286, \mathrm{p}<.001$ and self-efficacy: $\beta=.104, \mathrm{t}_{612}=2.646, \mathrm{p}<.01$ ).

Table 6

Multiple regression of SCEQ scales as predictors of study outcomes

\begin{tabular}{|c|c|c|c|c|c|c|c|c|c|c|c|c|}
\hline \multirow{2}{*}{ SCEQ SCALES } & \multicolumn{3}{|c|}{ Average Test score } & \multicolumn{3}{|c|}{$\mathrm{N}^{\circ}$ repeated exams } & \multicolumn{3}{|c|}{ Satisfaction } & \multicolumn{3}{|c|}{ Key Skills } \\
\hline & B & Beta & $\mathrm{t}$ & B & Beta & $\mathrm{t}$ & B & Beta & $\mathrm{t}$ & B & Beta & $\mathrm{t}$ \\
\hline Appr. Workload & .218 & .117 & $2.97 *$ & $\begin{array}{l}- \\
.067\end{array}$ & $\begin{array}{l}- \\
.034\end{array}$ & -.682 & .099 & .070 & $2.32 *$ & .010 & .008 & .328 \\
\hline $\begin{array}{l}\text { Appr. } \\
\text { Assessment }\end{array}$ & $\begin{array}{l}- \\
.061\end{array}$ & -.033 & -.775 & .039 & .019 & .431 & $\begin{array}{l}- \\
.018\end{array}$ & -.012 & -.337 & .063 & .090 & $2.863 * *$ \\
\hline Good Teaching & .201 & .080 & 1.593 & -.511 & $\begin{array}{l}- \\
.182\end{array}$ & $\overline{3.84 * * *}$ & .725 & .454 & $11.36 * * *$ & .294 & .310 & $7.987 * * *$ \\
\hline Collegiality & .048 & .032 & .677 & $\begin{array}{l}- \\
.078\end{array}$ & $\begin{array}{l}- \\
.039 \\
\end{array}$ & -.777 & .198 & .160 & $3.94 * * *$ & .195 & .281 & $7.320 * * *$ \\
\hline $\mathrm{R}^{2}$ & $.025^{*}$ & & & $.038^{*}$ & & & $.289^{*}$ & $* * *$ & & $.261^{*}$ & & \\
\hline
\end{tabular}

Perceptions on outcomes. All of the 4 SCEQ scales, except for appropriate assessment, predict the number of repeated exams. Appropriate workload perceptions were found to 
be predictor of average test scores. Overall, appropriate assessment perceptions do not seem to determine significant effects on any of the outcomes. However, the other 3 SCEQ scales emerged as good predictors of qualitative outcomes. Hp2d is consequently partially confirmed.

\section{Process on Products}

Study approach on outcomes. Both deep and surface approaches to study emerged as reliable predictors of all outcomes (average test scores, number of repeated exams, satisfaction, and key skills) (Table 7), confirming Hp3.

Table 7

Multiple regression of study approaches as predictors of study outcomes

\begin{tabular}{|c|c|c|c|c|c|c|c|c|c|}
\hline \multicolumn{5}{|c|}{ Deep Approach } & \multicolumn{5}{|c|}{ Surface Approach } \\
\hline Criteria & $\mathrm{F}$ & $\mathrm{R}^{2}$ & Beta & $\mathrm{t}$ & Criteria & $\mathrm{F}$ & $\mathrm{R}^{2}$ & Beta & $\mathrm{t}$ \\
\hline $\begin{array}{l}\text { Average test } \\
\text { score }\end{array}$ & $10.886^{* * *}$ & .020 & .141 & $3.30 * * *$ & $\begin{array}{l}\text { Average test } \\
\text { score }\end{array}$ & $31.057 * * *$ & .054 & -.233 & $-5.573 * * *$ \\
\hline $\begin{array}{l}\mathrm{N}^{\circ} \text { of } \\
\text { repeated } \\
\text { exams }\end{array}$ & $5.725 * *$ & .010 & -.100 & $-2.393 * *$ & $\begin{array}{l}\mathrm{N}^{\circ} \text { of } \\
\text { repeated } \\
\text { exams }\end{array}$ & 2.433 & .004 & .065 & 1.560 \\
\hline Satisfaction & $36.673 * * *$ & .058 & .241 & $6.056 * * *$ & Satisfaction & $57.543 * * *$ & .088 & -.297 & $-7.586^{* * *}$ \\
\hline Key Skills & $76.306^{* * * *}$ & .113 & .337 & $8.735 * * *$ & Key Skills & $30.884 * * *$ & .049 & -.222 & $-5.557 * * *$ \\
\hline
\end{tabular}

Study process on outcomes. Lesson attendance is not a valid predictor of quantitative outcomes, but it is a valid predictor of satisfaction $\left(\beta=.157 ; \mathrm{t}_{612}=4.150 ; \mathrm{p}<.001\right)$ and of key skills $\left(\beta=.097 ; \mathrm{t}_{612}=2.78 ; \mathrm{p}<.01\right)$. Autonomy in learning is a good predictor of average test score $\left(\beta=-.148 ; \mathrm{t}_{612}=-3.46 ; \mathrm{p}<.001\right)$, number of repeated exams $(\beta=$ $\left..134 ; \mathrm{t}_{612}=-3.21 ; \mathrm{p}<.001\right)$ and satisfaction $\left(\beta=-.104 ; \mathrm{t}_{612}=-2.62 ; \mathrm{p}<.01\right)$ : the less a student studies with their peers, the worse their study outcome. Results seems to confirm Hp4, especially for autonomy in learning.

\section{Testing the Theoretical Model}

Through the analysis of the deviation or fit between the model supported by the data and an ideal one, the SEMS allowed the set of relationships described by a theoretical model to be tested. In the present study, Structural equation modelling analysis (Bentler, 1990; Byrne, 1998) was used to assess the associations between the different considered variables of the 3P learning process model. Root Mean Square Error of approximation (RMSEA), Standardised Root Mean Square Residual (SRMS), Comparative Fit Index (CFI), Non-normed fit (NNFI) and Normed Fit Index (NFI) were used as fit indexes (Hu \& Bentler, 1999).

As a first step (Model 1), an adapted version of the Biggs' 3P learning process model, focussing on academic achievement, was developed on the basis of the previous regression results and empirical evidence (Barattucci et al., 2017; Diseth, 2007; Lizzio et al., 2002; Trigwell et al., 2013). It considered the following measures: school grades, 
motivation, self-efficacy, appropriate workload and good teaching as presage factors; deep approach and surface approach as process factors; average test score and number of repeated exams, as learning outcomes. This first model contained all the possible relationships between the $3 \mathrm{P}$ model's variables. Fit indexes were not satisfactory: $\mathrm{Chi}^{2} / \mathrm{df}=4.24 ; \mathrm{RMSEA}=.069 ; \mathrm{CFI}=.796 ; \mathrm{NFI}=.783 ; \mathrm{NNFI}=.81 ; \mathrm{SRMR}=.172$.

In the second step (Model 2), the model was revised, deleting the non-significant relationships between the variables. The fit indexes were acceptable: RMSEA $=.054$; $\mathrm{CFI}=.91 ; \mathrm{NFI}=.90 ; \mathrm{NNFI}=.93 ; \mathrm{SRMR}=.113 ; \mathrm{Chi}^{2} / \mathrm{df}=3.09$. The path diagram is presented in Figure 2.

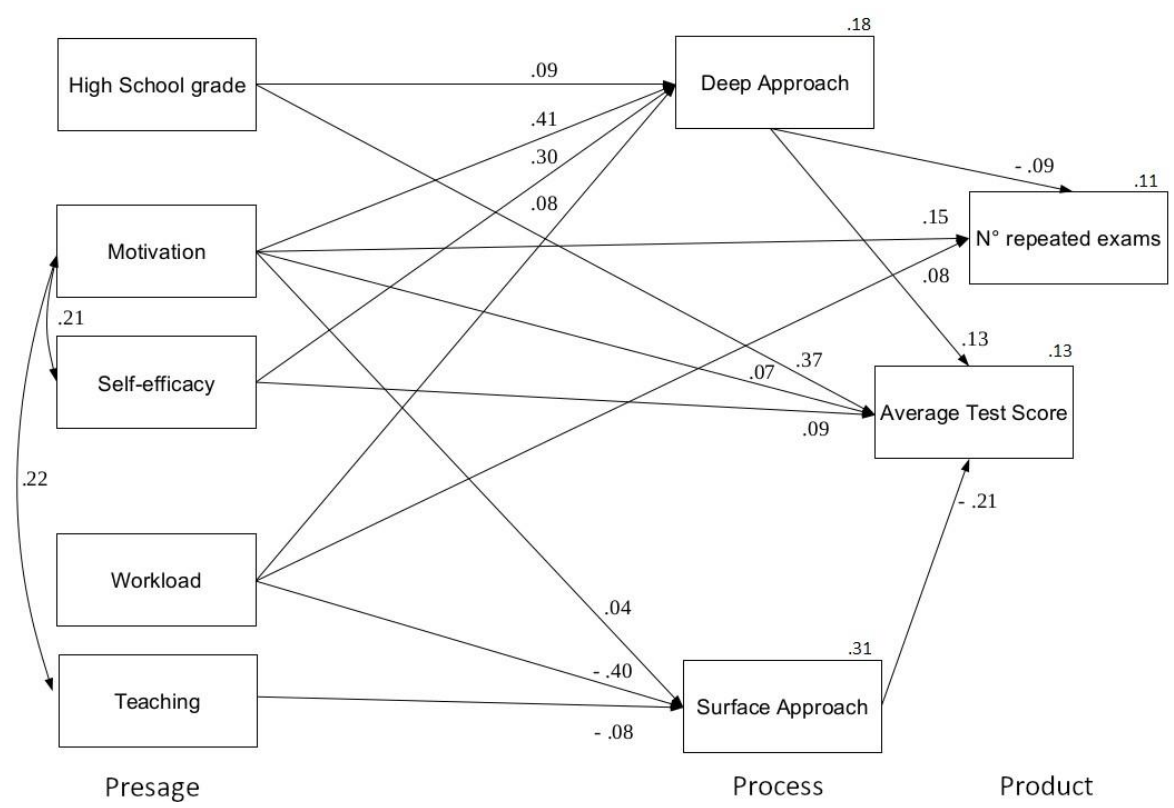

Figure 2

Path diagram of the tested model 2 of academic achievement

In the third step (Model 3), due to low and fewer significant relationships with other variables of the model, the previous model (Model 2) was used but with only average test score as learning outcomes and removing the good teaching scale measure. Fit index results were good: $\mathrm{Chi}^{2} / \mathrm{df}=1.87$; RMSEA $=.051 ; \mathrm{CFI}=.94 ; \mathrm{NFI}=.941 ; \mathrm{NNFI}=.959$; $\mathrm{SRMR}=.172 ; \mathrm{RMSEA}=.054 ; \mathrm{CFI}=.91 ; \mathrm{NFI}=.90 ; \mathrm{NNFI}=.93 ; \mathrm{SRMR}=.085)$. The path diagram is presented in Figure 3. Only three factors showed a direct effect on average test score: high school grade, surface and deep approach. Results seem to indicate that self-efficacy $(\beta=.29)$, motivation $(\beta=.41)$ and workload perceptions $(\beta=$ .11) have an indirect effect on academic achievement through deep and surface approach. The overall results support both $\mathrm{Hp} 1$ and Hp1a. 


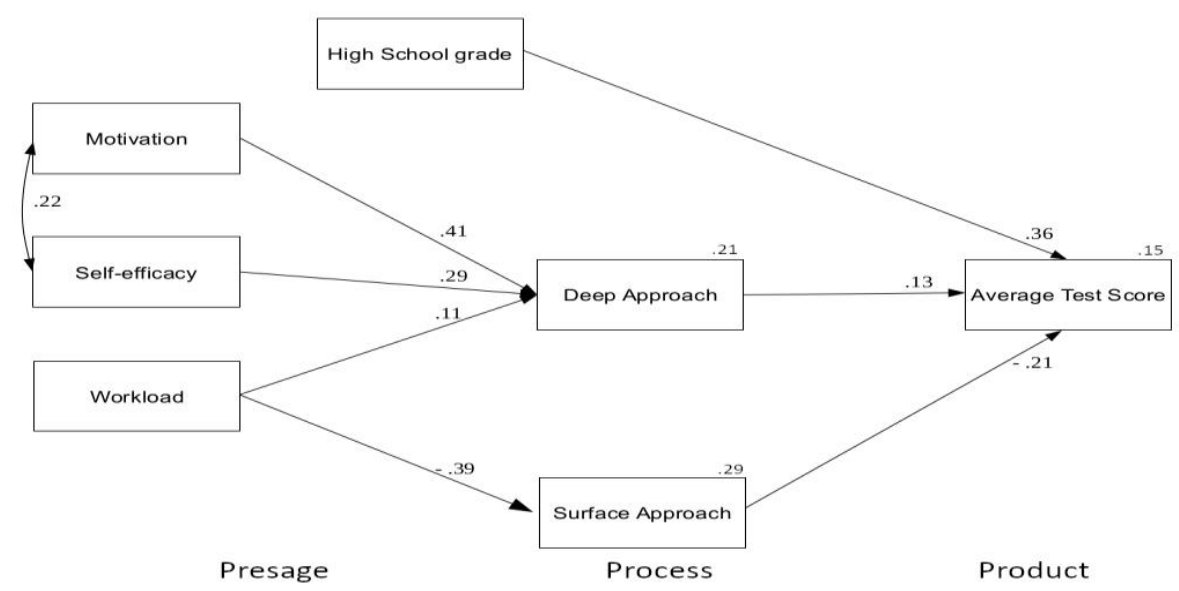

Figure 3

Path diagram of the tested model 3 of academic achievement

\section{Academic Delay}

A series of independent sample t-tests to check for differences between "on time" and "not on time" students were carried out (Table 8).

Table 8

Differences between on time students vs not on time students [mean value (SD)]

\begin{tabular}{lll}
\hline & On time $(\mathrm{N}=489)$ & Not on time $(\mathrm{N}=123)$ \\
\hline Age & $22.09(4.2)^{* * *}$ & $24.75(4.4)$ \\
\hline School grade & $85.13(12.01)^{* * *}$ & $78.17(11.12)$ \\
\hline Average Test Score & $26.20(1.4)^{* * *}$ & $25.29(1.8)$ \\
\hline Number of repeated exams & $1.85(1.9)^{* * *}$ & $3.39(2.3)$ \\
\hline Class attendance & $3.49(1.66)^{* * *}$ & $2.41(1.54)$ \\
\hline Autonomy in learning & $3.01(1.15)^{* * *}$ & $3.28(1.10)$ \\
\hline Satisfaction & $3.35(1.12)^{* *}$ & $3.09(1.05)$ \\
\hline Motivation & $4.14(0.55)^{* * *}$ & $3.91(0.61)$ \\
\hline Good Teaching & $2.87(0.98)^{*}$ & $2.55(0.87)$ \\
\hline$*=\mathrm{p}<.05 ; * *=\mathrm{p}<.01 ; * * *=\mathrm{p}<.001$ &
\end{tabular}

Differences emerged in relation to age $\left(\mathrm{t}_{611}=-3.658 ; \mathrm{p}<.001\right)$, school grade $\left(\mathrm{t}_{611}=\right.$ $5,903 ; \mathrm{p}<.001)$, motivation $\left(\mathrm{t}_{611}=4.360 ; \mathrm{p}<.001\right)$, good teaching $\left(\mathrm{t}_{611}=2.290 ; \mathrm{p}<\right.$ $.05)$, class attendance $\left(\mathrm{t}_{611}=6.550 ; \mathrm{p}<.001\right)$, autonomy in learning $\left(\mathrm{t}_{611}=-3.343 ; \mathrm{p}<\right.$ $.001)$, average test score $\left(\mathrm{t}_{611}=5.184 ; \mathrm{p}<.001\right)$, number of repeated exams $\left(\mathrm{t}_{611}=-\right.$ 7.654; $\mathrm{p}<.001)$ and satisfaction $\left(\mathrm{t}_{611}=2.609 ; \mathrm{p}<.01\right)$. Students not on time with their learning course plan reported lower scores of school grades, motivation and perceived teacher quality compared to on time students. Students not on time tend to study alone 
more than in groups, and to attend lessons less, achieving lower average test scores, repeating exams several times and being less satisfied. (Table 8). Results seems to support $\mathrm{Hp} 5$ but exclude study approach from the factors able to differentiate on time students and delayers.

\section{DISCUSSION}

The present research explored the impact of different factors on study approach and achievement. In particular, the study investigated which learning process factors most contribute to academic delay, in view of the Italian academic system which allows students who did not take all their annual scheduled exams to indefinitely postpone their degree course. Overall, results confirm the relationships expressed by the adapted Biggs' 3P Learning Process Model, and the effect of schooling background, motivation and course perceptions (teaching and workload) on learning outcomes through study approach (Diseth, 2007; Lizzio et al., 2002; Van Bragt, et al., 2011).

Results showed that prior school background (type of high school diploma, final high school grades and final undergraduate degree grade), personal factors (motivation and self-efficacy), and course perceptions (workload and teaching) directly predict learning outcomes. Compared to their on-time peers, not on time Italian psychology students have a lower prior school background level, lower class attendance, tend to study alone more than in peer groups, are less motivated and have worse perceptions of teaching quality.

For these Italian postgraduate students, confirming the literature (Barattucci et al., 2017; Trigwell et al., 2013), prior school background (type of high school diploma, final high school grades and final undergraduate degree grade) directly and indirectly (through approach to study), predicts academic delay. In line with previous studies (references) Motivation highly predicts the number of repeated exams and the other outcomes through study approach, while, unexpectedly, results seem to indicate that delay is not a matter of self-efficacy. Confirming past research regarding achievement (Fryer \& Ginns, 2017; Martin, 2019), teaching perceptions directly predict delay and through approach to study. Furthermore, the literature that highlights the role of academic social integration in study difficulties appears confirmed by the present results, which showed that studying in peer groups rather than alone leads to fewer repeated exams (CorneliusWhite \& Harbaugh, 2010; Mannan, 2007). This may be explained by the important role that group-study plays for students in retrieving information and notes about the assessment, tests, teacher preferences on specific issues, specifics of the didactic program and exercises. What seems clear is that, in Italian universities, as also demonstrated by the results of previous studies (Barattucci et al., 2017), the habit of studying in groups and taking part in university life, which involves peer exchange and reciprocal help, is somehow related to achievement and learning outcomes.

Among course perceptions, appropriate workload and teaching were the best predictors of both deep and surface approach to learning. In particular students with more appropriate workload perceptions are more likely to adopt a deeper approach to learning, while the higher perception the student has of the quality of teachers, the less they will adopt a surface approach to study (Fryer \& Ginns, 2017). Overall, the 
relationship between course perceptions and study approach was not fully clarified by the results of this study (Trigwell et al., 2013).

However, the results confirm that in the Italian academic context, study approach is a predictor of achievement (Barattucci et al., 2017) and highlighted that deep approach negatively predicts delay.

To summarise, schooling background, motivation, workload perceptions, deep approach and group study seem to contribute to academic path differences between students and delay, and should be given due consideration by Italian academic institutions and similar academic entities. Specific introductory courses for students with a low prior school background profile should be developed and integrated with the tutor system. Particular attention should be paid to implementing actions and practices which are able to facilitate socialisation processes aimed at study. In the academic context under review, group study seemed to facilitate new study methods learning and the achievement of learning standards which were able to positively influence learning outcomes. In addition to implementing motivational measures, as well as study strategy strengthening practices, the development of methodologies for forecasting academic delay or screening measures through data mining would be desirable (Cerezo et al., 2017; Hooshyar et al., 2020).

Various limitations of this study should be considered to better interpret the results and must be considered in the future. Firstly, although the 3P's learning process model has been successfully utilised in different academic systems (Barattucci et al., 2017; Barattucci \& Bocciolesi, 2018), it was developed and mainly used in closed campus universities and this may play an important role in determining the differences in students' contextual perceptions, which are determined by culture. Moreover, some limitations are linked to the nature of the non-random sampling and to the consequent generalisation of the results: a sample made up of students of a master's degree course in psychology does not necessarily represent the situation in other faculties or universities. The use of single-item measures for satisfaction and other background and outcomes variables also limited construct validity. In addition, we did not consider the development of student approaches to learning during studies that may account for the differences between undergraduate degree and master's degree students (Asikainen \& Gijbels, 2017).

Future research will need to consider a larger and more heterogeneous sample, with a focus on faculties, campus, departmental environment characteristics and differences.

\section{CONCLUSION}

The present research contributes to the literature confirming the overall positive association between approach to study and academic achievement. Furthermore, it highlights how autonomy in learning, workload, teaching perceptions and motivation seem to play an important role in academic delay. Prior school career, together with motivation levels and perceptions of teaching quality, should be particularly monitored to prevent academic delay or tendency to dropout. The interplay of personal (prior school and academic background, motivation and self-efficacy) and contextual factors should be observed by institutions, to implement differentiated actions and practices that 
support students with introductory lessons, scheduled peer tutoring, study methodologies and other specific on-demand services.

From an application point of view, this study suggests that faculties should invest more in the area of assessing predictive factors of academic delay and in delay management strategies and services.

Since some studies indicate that academic difficulties may be linked to inadequate academic support (Mannan, 2007; Zacks \& Hen, 2018), it is certainly necessary to focus on forecasting tools for learning difficulties and appropriate instructional support services.

\section{REFERENCES}

Anderson, J. C., \& Gerbing, D. W. (1988). Structural equation modelling in practice: A review and recommended two-step approach. Psychological Bulletin, 103(3), 411-423. https://doi.org/10.1037/0033-2909.103.3.411

Asikainen, H., \& Gijbels, D. (2017). Do students develop towards more deep approaches to learning during studies? A systematic review on the development of students' deep and surface approaches to learning in higher education. Educational Psychology Review, 29(2), 205-234. https://doi.org/10.1007/s10648-017-9406-6

Baeten, M., Dochy, F., \& Struyven, K. (2013). The effects of different learning environments on students' motivation for learning and their achievement. British Journal of Educational Psychology, 83(3), 484-501. doi: 10.1111/j.20448279.2012.02076. $\mathrm{x}$

Barattucci, M., \& Bocciolesi, E. (2018). Phenomenography in the Student Learning Perspective: a review of studies in academic contexts. Encyclopaideia - Journal of Phenomenology and Education, 22(50), 21-34. https://doi.org/10.6092/issn.1825$8670 / 7900$

Barattucci, M., \& Zuffo, R. G. (2012). Measuring learning environment perceptions: validation of the Italian version of the approaches to studying inventory and the student course experience questionnaire. Testing, Psychometrics, Methodology in Applied Psychology - TPM, 19(1), 15-33. doi: 10.4473/TPM19.1.2

Barattucci, M., Pagliaro, S., Cafagna, D., \& Bosetto, D. (2017). An examination of the applicability of Biggs' 3P learning process model to Italian university. Journal of $e$ Learning and Knowledge Society, 13(1), 163-180.

Bembenutty, H., \& Karabenick, S.A. (2004). Inherent Association Between Academic Delay of Gratification, Future Time Perspective, and Self-Regulated Learning. Educational Psychology Review, 16, 35-57. https://doi.org/10.1023/B:EDPR.0000012344.34008.5c

Bentler, P. M. (1990). Comparative fit index in structural models. Psychological Bulletin, 107(2), 238-246. https://doi.org/10.1037/0033-2909.107.2.238 
Biggs, J. (2003). Teaching for quality learning at university (2nd ed.). Berkshire, UK: Open University Press.

Biggs, J. B. (1989). Approaches to the enhancement of tertiary teaching. Higher Education Research and Development, 8(1), 7-25.

Biggs, J., \& Tang, C. (2007). Teaching for quality learning at university. Berkshire, UK: Society for Research into Higher Education and Open University Press.

Braxton., Milem, J.F., \& Sullivan, A.S. (2000). The influence of active learning on the college student departure process: toward a revision of Tinto's theory. Journal of Higher Education, 71(5), 569-590.

Byrne, B. M. (1998). Structural equation models with Lisrel, Prelis, and Simplis: Basic concepts, applications, and programming. NY: Lawrence Erlbaum Associates.

Byrne, M., Flood, B., \& Willis, P. (2002). The relationship between learning approaches and learning outcomes: a study of Irish accounting students. Accounting Education, 11(1), 27-42. doi: 10.1080/09639280210153254

Cerezo, R., Esteban, M., Sánchez-Santillán, M., \& Núñez, J. C. (2017). Procrastinating behavior in computer-based learning environments to predict performance: A case study in Moodle. Frontiers in Psychology, 8(1403), 1-11. https://doi.org/10.3389/fpsyg.2017.01403

Cornelius-White, J. H. D., \& Harbaugh, A.P. (2010). Learner-centred instruction: Building relationships for student success. London, UK: Sage Publications.

de la Fuente, J. (2017). Theory of self- vs. externally-regulated learning TM: Fundamentals, evidence, and applicability. Frontiers in Psychology, 8(1675), 1-14. doi: 10.3389/fpsyg.2017.01675

Diseth, $\AA$. (2007). Approaches to learning, course experience and examination grade among undergraduate psychology students: testing of mediator effects and construct validity. Studies in Higher Education, 32(3), 373-388. doi: 10.1080/03075070701346949

Diseth, A. (2013). Personality as an indirect predictor of academic achievement via student course experience and approach to learning. Social Behavior and Personality: An International Journal, 41(8), 1297-1308. https://doi.org/10.2224/sbp.2013.41.8.1297

Diseth, A., \& Kobbeltvedt, T. (2010). A mediation analysis of achievement motives, goals, learning strategies, and academic achievement. British Journal of Educational Psychology, 80, 671-687. http://doi.org/czhtgt

Entwistle, N. J., \& McCune, V. (2004). The conceptual bases of study strategy inventories in Higher Education. Educational Psychology Review, 16(4), 325-346. doi: 10.1007/s10648-004-0003-0 
Fryer, L. K., \& Ginns, P. (2017). A reciprocal test of perceptions of teaching quality and approaches to learning: A longitudinal examination of teaching-learning connections. Educational Psychology, 38(8), 1-18. http://doi.org/10.1080/01443410.2017.1403568

Geisinger, B.N., \& Raman, D.R. (2013). Why They Leave: Understanding Student Attrition from Engineering Majors. International Journal of Engineering Education, 29(4), 914-925.

Hattie, J. (2009). Visible learning: A synthesis of over 800 meta-analyses relating to achievement. New York, NY: Routledge.

Hen, M., \& Goroshit, M. (2018). The effects of decisional and academic procrastination on students' feelings toward academic procrastination. Current Psychology, 39, 556-563. doi: 10.1007/s12144-017-9777-3

Hooshyar, D., Pedaste, M., \& Yang, Y. (2020). Mining educational data to predict students' performance through procrastination behavior. Entropy, 22(1), 12. https://doi.org/10.3390/e22010012

Howie, P., \& Bagnall, R. (2013) A critique of the deep and surface approaches to learning model. Teaching in Higher Education, 18(4), 389-400. http://dx.doi.org/1 0.1080/13562517.2012.7336890.

Hu, L., \& Bentler, P. M. (1999). Cut-off criteria for fit indexes in covariance structure analysis: Conventional criteria versus new alternatives. Structural Equation Modelling, 6(1), 1-55. http://dx.doi.org/10.1080/10705519909540118

Jöreskog, K. G., \& Sörbom, D. (2001). LISREL 8: User's reference guide. Chicago: Scientific Software International.

Karagiannopoulou, E., \& Milienos, F. S. (2015). Testing two path models to explore relationships between students' experiences of the teaching-learning environment, approaches to learning and academic achievement. Educational Psychology, 35(1), 2652. doi:10.1080/01443410.2014.895800

Lizzio, A., Wilson, K., \& Simons, R. (2002). University students' perceptions of the learning environment and academic outcomes: Implications for theory and practice. Studies in Higher Education, 27(1), 27-52. http://doi.org/b5mtx5

Lo, M. L. (2012). Variation theory and the improvement of teaching and learning. Göteborg, SE: Acta Universitatis Gothoburgensis.

Lo, M. L., \& Marton, F. (2012). Towards a science of the art of teaching: Using Variation Theory as a guiding principle of pedagogical design. International Journal of Lesson and Learning Studies, 1(1), 7-22. doi:10.1108/20468251211179678

Lowinger, R. J., Kuo, B.C.H., Song, H.-A, Mahadevan, L., Kim, E., Liao, K. Y-H., Chang, C. Y., Kwon, K.-A., \& Han, S. (2016). Predictors of Academic Procrastination in Asian International College Students. Journal of Student Affairs Research and Practice, 53(1), 90-104. doi: 10.1080 / 19496591.2016.1110036 
Magnano, P., Lodi, E., \& Boerchi, D. (2020). The Role of Non-Intellective Competences and Performance in College Satisfaction. Interchange. https://doi.org/10.1007/s10780-019-09385-X

Malau-Aduli, B. S., Ray, R. A., O’Connor, T., van der Kruk, Y., Alele, F. O., \& Bellingan, M. (2020). Dealing with Academic Difficulty in Medical School: A Pilot Study. Education Sciences, 10(83), 1-8. https://doi.org/10.3390/educsci10030083

Mannan, M.A. (2007). Student attrition and academic and social integration: Application of Tinto's model at the University of Papua New Guinea. Higher Education, 53, 147-165. https://doi.org/10.1007/s10734-005-2496-y

Martin, A. J. (2019). Educational psychology and student learning: The potential of load reduction instruction for exploring surface and deep approaches to learning. The Psychology of Education Review, 43(1), 23-27.

Navarro, J. J., García-Rubio, J., \& Olivares, P. R. (2015). The relative age effect and its influence on academic performance. PLOS ONE, 10(10), 1-18. doi:10.1371/journ al. pone. 0141895

Neuville, S., Frenay, M., Schmitz, J., Boudrenghien, G., Noël, B., \& Wertz, V. (2007). Tinto's theoretical perspective and expectancy-value paradigm: A confrontation to explain freshmen's academic achievement. Psychologica Belgica, 47(1-2), 31-50. https://doi.org/10.5334/pb-47-1-31

Paul, G., Hinman, G., Dottl, S., \& Passon, J. (2009). Academic development: A survey of academic difficulties experienced by medical students and support services provided. Teaching and Learning in Medicine, 21, 254-260. http://dx.doi.org/10.1080/10401330903021041

Perchinunno, P., Bilancia, M., \& Vitale, D. (2019). A Statistical Analysis of Factors Affecting Higher Education Dropouts. Social Indicators Research, 1-23. https://doi.org/10.1007/s11205-019-02249-y

Pintrich, P. R., \& Schunk, D. H. (2002). Motivation in education: Theory, research and applications. Upper Saddle River, NY: Pearson/Merrill Prentice Hall

Pintrich, P. R., Smith, D.A.F., McKeachie, W.J. (1989). A manual for the use of the motivated strategies for learning questionnaire (MSLQ). National Center for Research to Improve Post-Secondary Teaching and Learning. The University of Michigan, Ann Arbor.

Prosser, M., Martin, E., Trigwell, K., Ramsden, P., \& Lueckenhausen, G. (2005). Academics' experiences of understanding of their subject matter and the relationship of this to their experiences of teaching and learning. Instructional Science, 33(2), 137-157. 10.1007/s11251-004-7687-X

Richardson, M., Abraham, C., \& Bond, R. (2012). Psychological correlates of university students' academic performance: A systematic review and meta-analysis. Psychological Bulletin, 138, 353-387. http://dx.doi.org/10.1037/a0026838

Santisi, G., Magnano, P., Platania, S., Ramaci, T. (2018). Psychological resources, satisfaction, and career identity in the work transition: An outlook on Sicilian college 
students. Psychology Research and Behavior Management, 11, 187-195. https://doi.org/10.2147/PRBM.S164745

Schneider, M., \& Preckel, F. (2017). Variables associated with achievement in higher education: A systematic review of meta-analyses. Psychological Bulletin, 143(6), 565600. http://dx.doi.org/10.1037/bul0000098

Spinath, B., Eckert, C., \& Steinmayr, R. (2014). Gender differences in school success: What are the roles of students' intelligence, personality and motivation? Educational Research, 56(2), 230-243. https://doi.org/10.1080/00131881.2014.898917

Steinmayr, R., Meißner, A., Weidinger, A. F., \& Wirthwein, L. (2015). Academic Achievement. In Oxford Bibliographies Online: Education. Retrieved 28 April, 2020 from http://www.oxfordbibliographies.com/view/document/obo-9780199756810/obo9780199756810-0108.xml

Tight, M. (2016). Phenomenography: the development and application of an innovative research design in higher education research. International Journal of Social Research Methodology, 19(3), 319-338. https://doi.org/10.1080/13645579.2015.1010284

Tinto, V. (2007). Research and Practice of Student Retention: What Next? Journal of College Student Retention Research Theory and Practice, 8(1), 1-19. doi: 10.2190/c0c4-eft9-eg7w-pwp4

Trigwell, K., Ashwin, P., \& Millan, E. S. (2013). Evoked prior learning experience and approach to learning as predictors of academic achievement. British Journal of Educational Psychology, 83, 363-378. doi: 10.1111/j.2044-8279.2012.02066.x

Van Bragt, C. A. C., Bakx, A. W. E. A., Bergen, T. C. M., \& Croon, M. A. (2011). Looking for students' personal characteristics predicting study outcome. Higher Education, 61(1), 59-75. doi: 10.1007/s10734-010-9325-7

Ward, P. J. (2011). Influence of study approaches on academic outcomes during preclinical medical education. Medical Teacher, 33(12), 651-662. doi: 10.3109/0142159X.2011.610843.

Wright, E., \& Osman, R. (2018). What is critical for transforming higher education? The transformative potential of pedagogical framework of phenomenography and variation theory of learning for higher education. Journal of Human Behavior in the Social Environment, 28(3), 257-270. doi: 10.1080/10911359.2017.1419898

Yonker, J. E. (2011). The relationship of deep and surface study approaches on factual and applied test-bank multiple-choice question performance. Assessment \& Evaluation in Higher Education, 36(6), 673-686. doi: 10.1080/02602938.2010.481041

Zacks, S., \& Hen, M. (2018) Academic interventions for academic procrastination: A review of the literature. Journal of Prevention \& Intervention in the Community, 46(2), 117-130. doi: 10.1080 / 10852352.2016.1198154

Zeegers, P. (2004). Student learning in higher education: A path analysis of academic achievement in science. Higher Education Research and Development, 23(1), 35-56. doi:10.1080/0729436032000168487 